\title{
Effects of the Application of Multimedia to Library Use Education on Learning Motivation and Learning Satisfaction
}

\author{
Kaijun Yu ${ }^{1}$, Hongmei Tang ${ }^{2}$, Ruiyi Gong ${ }^{1 *}$, Jianzhong Dong ${ }^{3}$, Shanshan $\mathrm{Hu}^{1}$ \\ ${ }^{1}$ Library, Shanghai University of Medicine \& Health Sciences, Shanghai, CHINA \\ 2 School of Nursing and Health Management, Shanghai University of Medicine \& Health Sciences, Shanghai, CHINA \\ ${ }^{3}$ Library, Shanghai University of Electric Power, Shanghai, CHINA
}

Received 9 December 2017 • Revised 21 April 2018 • Accepted 5 May 2018

\begin{abstract}
The use of libraries is considered as the best method to catch up with the time and learn new information in the modern busy society. For an ideal learning society, a library is the most convenient learning center for the public and conforms to the philosophy of self-relearning in lifelong education. It is the most important unit to connect school education and community education as well as the most possible power to implement lifelong education with the combination of the government and the civil. With experimental design model, total 180 students in Shanghai University of Medicine \& Health Sciences, as the research object in this study, are proceeded the 15week (3 hours per week for total 45 hours) experiment applying multimedia to library use education. The research results show significant correlations between 1.library use education and learning motivation, 2.library use education and learning satisfaction, and 3.learning motivation and learning satisfaction. According to the results, suggestions are proposed, expecting to enhance students' library resource use and use frequency to promote learning motivation and learning satisfaction.
\end{abstract}

Keywords: multimedia, library use education, learning motivation, learning satisfaction

\section{INTRODUCTION}

With "holistic education" as the goal, "life education" as the basis, "lifelong education" as the spirit, and "complete learning" as the process, it aims to cultivate good nationals of the society and good citizens of the world to make the nation be more competitive and the people live better. For an ideal learning society, a library is the most convenient learning center for the public and conforms to the philosophy of self-relearning in lifelong education. It is the most important unit to connect school education and community education as well as the most possible power to implement lifelong education with the combination of the government and the civil. Overall speaking, the role of a library in students' self-learning is not obvious. It is the priority for all libraries to match current lifelong education policies and reinforce the promotion of library service and function. A good library is a treasure house of knowledge as well as the source of wisdom. In the modern busy society, the use of library is the best way to catch up with the time and learn new information. Besides, students' reading ability would directly affect the subject learning that reading achievement is an important indicator of reading efficacy at school. The earlier application of correct reading could help the development of brain and language. For this reason, the reading guidance of a library is the focus of library service to guide students' reading interests and ability. School libraries positively utilize the collections for reading promotion to enhance the reading atmosphere on campus.

A library is a non-profit institution aiming to provide service and play the role of supporting teaching, research, promotion, and service. In traditional library environment, the frontline librarians used to be the first impression of readers about the library service quality. Now, in the Internet environment, readers would judge the library service quality by the offered network resources and services. In this case, having students know the environment and facilities of school libraries and guiding them the use method could have students learn to utilize library

(C) 2018 by the authors; licensee Modestum Ltd., UK. This article is an open access article distributed under the terms and conditions of the Creative Commons Attribution License (http://creativecommons.org/licenses/by/4.0/). \yukj@sumhs.edu.cn $\boldsymbol{M}$ tanghm@sumhs.edu.cn $\boldsymbol{M}$ gongry@sumhs.edu.cn (*Correspondence) 


\section{Contribution of this paper to the literature}

- Students have to use school library for the reading. However, the collections in school library cannot satisfy most students' needs. In this case, the cross-school and cross-district joint library lending system could be established.

- The function of a school library should be developed the maximum effectiveness. In addition to the positive promotion, it relies on teachers integrating multimedia into teaching activity and course design so that students would really regard school libraries as an important learning channel.

- School teachers with interests in library science should be encouraged to participate in off-campus seminars and trainings to become the seed teachers of the school and design the school-based curricula conforming to the school situation.

resources and present autonomous learning to enhance the learning motivation and learning satisfaction. Multimedia is therefore applied to library use education for understanding the effect on students' learning motivation and learning satisfaction in this study. It is expected to enhance students' library resource use and use frequency to promote the learning motivation and learning satisfaction.

\section{LITERATURE REVIEW}

\section{Multimedia Teaching}

Chiang, Lin, and Hwu (2013) considered that computers could attract students' attention through vivid images, fresh colors, and texts \& sound to further enhance students' learning concentration and interests. For information integrated teaching, it is an important issue to well apply network resources in the network development era. A lot of computer-assisted teaching systems are developed in order to help teachers guide students using network resources. Hsu, Huang, and Hsieh (2014) defined multimedia as texts and pictures. Texts referred to language types, including written visual texts and oral expression texts; pictures, as image types, contained static pictures (illustration, hodograph, diagram, photo, and map) and dynamic pictures (animation and film). Abdi (2013) proposed multimedia learning derivatives, which emphasized that all learning should go through three processes of selection, organization, and integration of pictures and texts. Selection referred to selecting related and important information from text and non-text information and storing in working memory, then the selected text and nontext information were organized and established the structure to form two situational models conforming to the logic, and finally the two organized situational models were integrated and combined. Multimedia learning referred to the utilization of text and picture learning that multimedia learning could be called dual-code learning or dual-channel learning, i.e. multimedia presentation as information being presented with texts and pictures. Multimedia teaching information or multimedia teaching presentation explained learning with texts and pictures (Ihmeideh, 2014; Wu \& Tai, 2016; Yi, 2017; Ferreira, Baptista \& Arroio, 2013; Alves, Ribeiro, Cunha, Pereira, \& Pinto, 2016; Abbasi, Moeini, Shahriari, Ebrahimi, \& Khoozani, 2018).

\section{Library Use Education}

Clark (2013) indicated that library use education was to teach students knowing school library environment and facilities and guide students of reading methods; meanwhile, it allowed students learning the utilization of library resources to present autonomous learning. It was further explained that library use education contained 1.allowing students knowing library services - printing manuals, making introduction $\mathrm{CD}$, and multimedia interpretation, and leading visits, 2.guiding students to apply library collections - use guidelines and special bibliography guidelines, and holding seminars, and 3.online library use instruction and teaching activity. Al-Awidi and Ismail (2014) explained broad and narrow library use education. The former referred to library use education from elementary school, high school, university to entering the society, aiming at readers' learning for knowledge to develop the research and creation objectives, and further develop to special objectives for different industries. The latter referred to the library use counseling education practiced with formal education at the school learning stage. Issa et al. (2013) indicated that the practice at elementary school, high school, and university stages focused on the use of school libraries, teaching students about the use of library service and the knowledge and skills of collections. Owing to the rapid development of information technology and the changes of students' reading habits, Hsu, Chang, and Hsieh (2015) proposed to rename library use education as "library information use education", aiming to have the content of library use education based on information literacy to teach all teachers and students the skill to utilize printed, non-printed, and electronic resources. 
Referring to Hsu et al. (2015), library use education contains the following dimension in this study.

(1) Service dimension: including "knowing library", "understanding library service", and "use equipment \& resources".

(2) Information literacy: containing "understanding the value of information", "effective independent information enquiry", "information evaluation", and "organization and use of information".

(3) Lifelong learning: covering "cultivation of computer literacy", "cultivation of media literacy", and "cultivation of network literacy".

\section{Learning Motivation}

Grove, Burns, and Gray (2013) proposed that learning motivation was not naturally affected by environment and reinforcers; there were many factors in students' learning motivation, including school, teachers, peers, course materials, and off campus. Parish et al. (2013) further indicated that, in specific situations, students with learning motivation were willing to positively learn, could well apply the resource management strategy to learn time planning, overcome learning difficulty and seek for support, continuously learn, and construct knowledge with learned cognitive strategies to achieve the learning goal. Alickovic and Subasi (2016) regarded learning motivation as individual psychological needs for pursuing success, i.e. learners finding out the meaning and value of learning activity and attempting to pursue the growth. Jhang (2014) proposed that students remained the study and learning activity, and learning could have students automatically engage in maintaining the learning motive. Saelao, Tubsree, and Markwardt (2016) defined learning as the process acquiring knowledge and changing behaviors due to experiences. Conejeros and Mansilla (2014) also indicated that learning motivation could have an individual be more positive on learning in order to maintain learning activity and continue the behavior towards the learning goal. Terrazas-Arellanes, Knox, Strycker, and Walden (2016) stated that learning motivation could induce individual learning activity and maintain the learning activity to have the activity move toward certain learning goal.

Referring to Huang and Chuang (2016), learning motivation includes the dimensions of knowledge interests and external expectation in this study.

(1) Knowledge interests: To maintain and guide the process of study and learning activity, automatically invest the efforts in the learning, and maintain the learning motive.

(2) External expectation: To participate in learning for following the instruction or satisfying the expectation of external others, who were normally authorities, including parents, family members, employers, and even other adult learners.

\section{Learning Satisfaction}

Jin, Zhao, Chow, and Pecht (2014) considered that the closer relationship between teachers and students would enhance students' satisfaction with the teachers, and the more course content conforming to students' learning needs and interests could better promote students' learning satisfaction. Yuan, Powell, and CETIS (2013) pointed out the meaning of learning satisfaction as learners' inner feelings and attitudes in the learning process and the degree of learners' desires and needs for learning being satisfied and achieved. Coombs, Curtis, and Crookes (2013) discovered that learning satisfaction referred to learning activity satisfying personal needs as well as learners, in the learning process, being able to perceive learning activity and satisfy personal learning needs to generate good perception and positive attitudes. Qi, Tian, and Shi (2013) also pointed out learning satisfaction as students' feelings and attitudes, during or after learning; when they felt happy or presented positive attitudes, it was satisfaction; on the contrary, they were dissatisfied when feeling unhappy or presenting negative behaviors. Doherty and Thompson (2014) proposed that learners acquiring satisfaction and finding out pleasure in the learning would remain the motivation for continuous learning. In this case, learning satisfaction was an important indicator to measure learning outcome and learner satisfaction with learning as well as the judgment standard to induce learners' motivation for course design or efficacy success.

Course content, teaching methods, and learning methods, proposed by Cheng et al. (2016), are regarded as the dimensions to measure learning satisfaction in this study.

(1) Course content: new knowledge in the course, explanation of contents, rich courses, and diverse courses.

(2) Teaching methods: evaluation of assignment, multimedia teaching methods, teaching interactivity of courses, lively teaching methods.

(3) Learning methods: interface operation, home learning, control of learning time, repeatedly viewing course content. 


\section{Research Hypothesis}

Hsu et al. (2015) mentioned that the advance of the time changed the idea of a library being simply a book storage building. Particularly, the rapid growth of human knowledge and the increasing accumulation resulted in readers being difficult to thoroughly and effectively utilize the organization, classification, and search method for book information without certain guidance (Clark \& Mayer, 2016). Through library use education, readers could realize the importance of information in life and pay attention to the application in life. Meanwhile, cultivating readers' information retrieval ability could reduce librarians' business loads to further use the time for offering better service. Furthermore, the use education process could build the professional image of librarians and enhance the status of a library (Türk \& Erçetin, 2014). Lin and Wu (2013) regarded library use education as to teach readers knowing a library and further instruct readers to use various library resources and services to enhance the information search ability, effectively and thoroughly apply various library supports to self-research and learning so as to establish the lifelong learning ability. Al-Awidi and Ismail (2014) stated that a school library could cultivate students' information literacy and establish the lifelong learning basis through library use education. Accordingly, the following hypothesis is proposed in this study.

H1: Library use education shows significant correlations with learning motivation.

Mireku (2016) pointed out three reasons for the practice of library use education. 1. The diverse contents of library use education could educate students to effectively apply distinct information. 2 . Knowledge was not passively, but constructed by learners; and, use education was to educate students to self-construct knowledge with information. 3. Education in the new era paid attention to the cultivation of learning attitude and ability; and, use education could have students cultivate the positive and active self-learning habit. Hsiao, Tsai, and Kao (2013) regarded the importance of library use education as the sequence of enhancing students' self-learning ability, cultivating students' library and information use ability, cultivating students' lifelong learning habit, and changing students' learning method and attitude. Niknejad and Rahbar (2015) indicated that the practice of library use education could enhance students' library use frequency, promote the information application ability, and cultivate the lifelong learning habit. After accepting library use education, teachers could apply it to real teaching and deepen and broaden students' learning with rich teaching contents and methods (Alickovic \& Subasi, 2016). The following hypothesis is therefore proposed in this study.

H2: Library use education reveals remarkable correlations with learning satisfaction.

Uysal and Gunal (2014) discussed the relationship between learning motivation and learning satisfaction of students in Department of Beauty Science and proved the significantly positive relationship. Morgan (2013) mentioned the positive correlation between learning motivation and learning satisfaction that learning motivation not being satisfied would not appear satisfactory learning results. Cheng et al. (2016) studied the members of Digital Machine Association Center and found out the positive correlation between the learning motivation and learning satisfaction, i.e. members with stronger learning motivation presenting higher learning satisfaction. Ross et al. (2014) discovered that the higher learning motivation would show higher learning satisfaction, and learning motivation presented predictability on learning satisfaction. Research found out the stronger learning motivation, the higher learning satisfaction. Learning satisfaction was not simply the evaluation indicator of learning results, but the major indicator to induce learning motivation and develop curricula. Doherty and Thompson (2014) found out the remarkably positive correlation between learning motivation and learning satisfaction. Sullivan (2015) pointed out notable correlations between students' learning motivation and learning satisfaction that the stronger motivation appeared the higher learning satisfaction. As a result, the following hypothesis is proposed in this study.

H3: Learning motivation presents notable correlations with learning satisfaction.

\section{RESEARCH METHOD}

\section{Method and Model}

The test for goodness-of-fit with LISREL could be measured from the overall model fit (external quality of model) and internal quality of model. Regarding the overall model fit, the common goodness-of-fit indices contain (1) " $\chi 2$ ratio" (Chi-Square ratio), presenting the gap between actual theoretical model and expected value, which is better smaller than 3, (2) goodness-of-fit index (GFI) and adjusted goodness-of-fit index (AGFI), which reveal the better goodness of fit when being closer to 1, (3) root mean square residual (RMR) of the square root of "fit residual variance/covariance mean", which is better smaller than 0.05 , and (4) incremental fit index (IFI), which presents good model fit when being higher than 0.9 .

The common evaluation indicators of internal model quality with LISREL include (1) SMC (square multiple correlation) of individual manifest variable, i.e. R2 of manifest variables and latent variables, which should be larger than $0.5,(2)$ component reliability $(\rho)$ of latent variables, as the Cronbach's a of the observation indicator of latent 
Table 1. Model analysis result

\begin{tabular}{|c|c|c|c|}
\hline 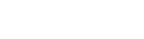 & Evaluation indicator & Judgment standard & Result \\
\hline & $p$-value & $p$-value $>0.05$ & 0.000 \\
\hline & $x 2 /$ d.f. & $<3$ & 1.283 \\
\hline & $\mathrm{GFI}$ & $>0.9$ & 0.976 \\
\hline & AGFI & $>0.9$ & 0.921 \\
\hline \multirow[t]{5}{*}{ Overall fit } & $\mathrm{CFI}$ & $>0.9$ & 0.963 \\
\hline & RMR & $<0.05$, better lower than 0.025 & 0.014 \\
\hline & RMSEA & $\begin{array}{c}0.05 \sim 0.08 \text { good } \\
\text { better lower than } 0.05\end{array}$ & 0.043 \\
\hline & $\mathrm{NFI}$ & $>0.9$ & 0.933 \\
\hline & $\mathrm{IFI}$ & $>0.9$ & 0.906 \\
\hline
\end{tabular}

Table 2. SMC of variable to dimension

\begin{tabular}{cc} 
& Learning motivation \\
\hline Knowledge interests & External expectation \\
\hline 0.74 & 0.78 \\
\hline
\end{tabular}

Table 3. SMC of variable to dimension

\begin{tabular}{cccccc}
\hline \multicolumn{2}{c}{ Library use education } & & \multicolumn{2}{c}{ Learning satisfaction } \\
\hline Service dimension & Information literacy & Lifelong learning & Course content & Teaching methods & Learning methods \\
\hline 0.72 & 0.76 & 0.82 & 0.75 & 0.82 & 0.84 \\
\hline
\end{tabular}

variables, which should be larger than 0.6 , and (3) average variance extracted of latent variables, which is calculated by the R2 sum of manifest variables of a latent variable divided by the number of manifest variables, revealing the percentage of latent variables being measured through manifest variables, which is better larger than 0.5.

\section{Research Sample and Object}

With experimental design model, total 180 students in Shanghai University of Medicine \& Health Sciences, as the research object, are proceeded the 15-week ( 3 hours per week for total 45 hours) experimental teaching with the application of multimedia to library use education.

\section{Reliability and Validity Test}

Validity refers to a measuring scale being able to actually measure the degree of what a researcher would like to measure. Common validity contains "content validity", which tends to qualitative test, "criterion validity", which is evaluated with set external criterion and the correlation coefficient in the test, and "construct validity", which is used for evaluating the consistency of the measurement with other observable variables. The questionnaire content in this study is based on past theories and refers to the actual conditions of the research object to ensure the content validity. The final commonality estimate of the Factor Analysis result is applied to test the construct validity of dimensions and the acquired validity appears in $0.7 \sim 0.9$ that the research questionnaire presents favorable validity.

\section{ANALYSIS OF EMPIRICAL RESULT}

\section{Model Fit Test}

The estimation with "Maximum Likelihood" (ML) is utilized in this study, and the analysis result achieves convergence. Overall speaking, the indicators of overall model fit pass the test, Table 1, thoroughly reflecting the favorable external quality of the model.

\section{Test of Path Relationship}

In terms of internal model quality test, SMC of manifest variables is higher than 0.5 (Table $2 \& 3$ ), revealing good measurement indicators of latent variables. Furthermore, latent variables of learning motivation, library use education, and learning satisfaction show the component reliability higher than 0.6 , and the average variance extracted of dimensions is higher than 0.5 (Table 4), conforming to the requirement for internal model quality. 
Table 4. Component reliability of variable and average variance extracted

\begin{tabular}{cccc}
\hline Item & Learning motivation & Library use education & Learning satisfaction \\
\hline Component reliability & $\mathbf{0 . 8 3 3}$ & $\mathbf{0 . 8 5 7}$ & $\mathbf{0 . 8 6 9}$ \\
\hline Average variance extracted & 0.81 & 0.83 & 0.84 \\
\hline
\end{tabular}

Table 5. Linear Structural Relations Model analysis

\begin{tabular}{cccc}
\hline Evaluation item & Parameter/Evaluation standard & Result & t \\
\hline \multirow{3}{*}{ internal goodness of fit } & library use education $\rightarrow$ learning motivation & 0.851 & $27.41^{\star \star}$ \\
\cline { 2 - 4 } & library use education $\rightarrow$ learning satisfaction & 0.884 & $34.25^{\star \star}$ \\
\cline { 2 - 4 } & learning motivation $\rightarrow$ learning satisfaction & 0.863 & $29.66^{\star \star}$ \\
\hline
\end{tabular}

Table 6. Hypothesis test

\begin{tabular}{ccccc}
\hline Research hypothesis & Correlation & Empirical result & p & Result \\
\hline $\mathrm{H} 1$ & + & 0.851 & 0.00 & supported \\
\hline $\mathrm{H} 2$ & + & 0.884 & 0.00 & supported \\
\hline $\mathrm{H} 3$ & + & 0.863 & 0.00 & supported \\
\hline
\end{tabular}

Table 5 reveals positive and significant correlations between library use education and learning motivation (0.851), library use education and learning satisfaction $(0.884)$, as well as learning motivation and learning satisfaction (0.863), that $\mathrm{H} 1, \mathrm{H} 2$, and $\mathrm{H} 3$ are supported. The test of research hypotheses in this study is shown in Table 6.

\section{CONCLUSION}

The research results reveal that "covering reading interests, habits, and methods" is the priority of the curriculum goal of school library use education, the course content focuses on "knowing library environment, function, and basic service", and it should be practiced by matching school reading promotion activity. Current library equipment should stress on network resources, as traditional paper-based books would be replaced by online reading. Besides, students generally search for data with computer networks, rather than traditional textbooks and knowledge in book. In this case, school library use education in the network era should instruct students of basic use and teach them how to use new information media. The application of network resources is especially important that online service of library should be equipped for students' use, and multimedia can be applied to library use education to promote reading. Library use education of teachers could benefit the teaching effectiveness, as teachers could select proper teaching strategies and resources, e.g. books, magazines, diagrams, and video \& audio media, as the assisted materials to guide students' learning to actively search, evaluate, organize, store, explain, communicate, and use information to enhance the learning depth and width.

\section{RECOMMENDATIONS}

By organizing the results and findings, practical suggestions are proposed as below.

1. Students have to use school library for the reading. However, the collections in school library cannot satisfy most students' needs. In this case, the cross-school and cross-district joint library lending system could be established. Meanwhile, school libraries could be open on holidays for students' use so as to enhance students' learning motivation and the overall learning atmosphere.

2. The function of a school library should be developed the maximum effectiveness. In addition to the positive promotion, it relies on teachers integrating multimedia into teaching activity and course design so that students would really regard school libraries as an important learning channel. Besides, students should be guided to use library resources at free time and a school library should increase relevant computer network hardware and network related resources conforming to student needs in order to attract the use of students and promote the learning satisfaction.

3. A school indeed would hold several professional trainings for teachers; however, not many teachers would participate, and those trainings even become not deeply discussing how to effectively practice library use education. In this case, school teachers with interests in library science should be encouraged to participate in off-campus seminars and trainings to become the seed teachers of the school and design the school-based curricula conforming to the school situation. 


\section{REFERENCES}

Abbasi, S., Moeini, M., Shahriari, M., Ebrahimi, M., Khoozani, E. K. (2018). Designing and manufacturing of educational multimedia software for preventing coronary artery disease and its effects on modifying the risk factors in patients with coronary artery disease. Electronic Journal of General Medicine, 15(3), em22. https:// doi.org/10.29333/ ejgm/85942

Abdi, R. (2013). The effect of using hypertext materials on reading comprehension ability of EFL learners. ProcediaSocial and Behavioral Sciences, 83, 557-562. https://doi.org/10.1016/j.sbspro.2013.06.106

Al-Awidi, H. M., \& Ismail, S. A. (2014). Teachers' perceptions of the use of computer assisted language learning to develop children's reading skills in English as a second language in the United Arab Emirates. Early Childhood Education Journal, 42(1), 29-37. https:/ / doi.org/10.1007/s10643-012-0552-7

Alickovic, E., \& Subasi, A. (2016). Medical decision support system for diagnosis of heart arrhythmia using DWT and random forests classifier. Journal of medical systems, 40(4), 1. https:/ / doi.org/10.1007/s10916-016-04678

Alves, C., Ribeiro, V., Cunha, M., Pereira, P., \& Pinto, C. (2016). GeoloGIS-BH: An Information System for Using the Built Heritage for Geological Teaching. European Journal of STEM Education, 1(3), 57. https://doi.org/10.20897/lectito.201657

Cheng, T. F., Lou, S. H., Wu, H. C., Tseng, S. F., \& Shih, R. C. (2016). The construction of benefit assessment indicators for technical high school through structural equation modeling (SEM). International Journal of Management and Applied Science, 2(3), 83-86.

Chiang, H. C., Lin, F. Y., \& Hwu, Y. J. (2013). Disability Assessment: The Efficacy of Multimedia Interactive Nurse Education. The Journal of Nursing Research, 21(2), 83-93. https:/ / doi.org/10.1097/jnr.0b013e3182921f5a

Clark, M. (2013). The use of technology to support vocabulary development of English Language Learners. Education Masters, (pp. 238).

Clark, R. C., \& Mayer, R. E. (2016). E-learning and the science of instruction: Proven guidelines for consumers and designers of multimedia learning. John Wiley \& Sons. https:/ / doi.org/10.1002/9781119239086

Conejeros, A. L., \& Mansilla, C. B. (2014). Evaluation of a rural self-learning English program in Chile. Enjoy Teaching Journal, 2(2).

Coombs, T., Curtis, J., \& Crookes, P. (2013). What is the process of a comprehensive mental health nursing assessment? Results from a qualitative study. International Nursing Review, 60(1), 96-102. https://doi.org/10.1111/j.1466-7657.2012.01036.x

Doherty, M., \& Thompson, H. (2014). Enhancing person-centred care through the development of a therapeutic relationship. British Journal of Community Nursing, 19(10), 502-507. https:/ / doi.org/10.12968/bjcn.2014.19.10.502

Ferreira, C., Baptista, M., Arroio, A. (2013). In-Service Training of Chemistry Teachers: The Use of Multimedia in Teaching Chemistry. Eurasia Journal of Mathematics, Science and Technology Education, 9(3), 301-310. https:/ / doi.org/10.12973/eurasia.2013.937a

Grove, S. K., Burns, N., \& Gray, J. (2013). The Practice of Nursing Research: Appraisal, Synthesis, and Generation of Evidence (seventh edition), St. Louis, Missouri: Elsevier.

Hsiao, C. Y., Tsai, Y. F., \& Kao, Y. C. (2013). Psychometric properties of a Chinese version of the Jefferson Scale of Empathy- Health Profession Students. Journal of Psychiatric \& Mental Health Nursing, 20(10), 866-873. https://doi.org/10.1111/jpm.12024

Hsu, L. L., Chang, W. H., \& Hsieh, S. I. (2015). The effects of scenario-based simulation course training on nurses" communication competence and self-efficacy: a randomized controlled trial. Journal of Professional Nursing, 31(1), 37-49. https:/ / doi.org/10.1016/j.profnurs.2014.05.007

Hsu, L. L., Huang, Y. H., \& Hsieh, S. I. (2014). The effects of scenario-based communication training on nurses" communication competence and self-efficacy and myocardial infarction knowledge. Patient Education $\mathcal{E}$ Counseling, 95(3), 356-364. https:/ / doi.org/10.1016/j.pec.2014.03.010

Huang, Y. H., \& Chuang, T. Y. (2016). Technology-assisted sheltered instruction: instructional streaming video in an EFL multi-purpose computer course. Computer Assisted Language Learning, 29(3), 618-637. https:/ / doi.org/10.1080/09588221.2014.1000933

Ihmeideh, F. M. (2014). The effect of electronic books on enhancing emergent literacy skills of pre-school children. Computers $\mathcal{E}$ Education, 79, 40-48. https:/ / doi.org/10.1016/j.compedu.2014.07.008 
Issa, N., Mayer, R. E., Schuller, M., Wang, E., Shapiro, M. B., \& DaRosa, D. A. (2013). Teaching for understanding in medical classrooms using multimedia design principles. Medical Education, 47(4), 388-396. https://doi.org/10.1111/medu.12127

Jhang, G. K. (2014). The research of Multimedia Image memory method used in elementary English vocabulary learning (Unpublished master's dissertation), Shu-Te University, (pp. 1-89).

Jin, X., Zhao, M., Chow, T. W., \& Pecht, M. (2014). Motor bearing fault diagnosis using trace ratio linear discriminant analysis. IEEE Transactions on Industrial Electronics, 61(5), 2441-2451. https:/ / doi.org/10.1109/TIE.2013.2273471

Lin, C. C., \& Wu, Y. C. (2013). The effects of different presentation modes of multimedia annotations on sentential listening comprehension. In Proceedings of the 21st International Conference on Computers in Education.

Mireku, A. A. (2016). The impact of Information and Communications Technology (ICT) on effective teaching of environmental education in rural high schools (Doctoral dissertation, University of Fort Hare).

Morgan, H. (2013). Multimodal children's e-books help young learners in reading. Early Childhood Education Journal, 41(6), 477-483. https:/ / doi.org/10.1007/s10643-013-0575-8

Niknejad, S., \& Rahbar, B. (2015). Enhancing EFL learners' reading comprehension ability through multimediabased visualization. Journal of Applied Linguistics and Language Research, 2(6), 119-127.

Parish, S. J., Stein, M. R., Hahn, S. R., Goldberg, U., \& Arnsten, J. H. (2013). Teaching and Assessing Residents' Skills in Managing Heroin Addiction with Objective Structured Clinical Examinations (OSCEs). Substance Abuse, 34(4), 350-355. https:/ / doi.org/10.1080/08897077.2013.776658

Qi, Z., Tian, Y., \& Shi, Y. (2013). Robust twin support vector machine for pattern classification. Pattern Recognition, 46(1), 305-316. https:// doi.org/10.1016/j.patcog.2012.06.019

Ross, J., Sinclair, C., Knox, J., Bayne, S., \& Macleod, H. (2014). Teacher Experiences and Academic Identity: The Missing Components of MOOC Pedagogy. MERLOT Journal of Online Learning and Teaching, 10(1), March 2014.

Saelao, S., Tubsree, C., \& Markwardt, R. A. (2016). The effect of online language learning on the English achievement of first-year undergraduate students. HRD JOURNAL, 6(2), 104-116.

Sullivan, L. M. (2015). The Effects of Embedded Considerate Multimedia Features on Digital Text Comprehension among Second and Third Grade Students of Different Reading Abilities (Doctoral dissertation, Johns Hopkins University).

Terrazas-Arellanes, F. E., Knox, C., Strycker, L. A., \& Walden, E. (2016). A Face-to-Face Professional Development Model to Enhance Teaching of Online Research Strategies. Journal of Information Technology Education, (pp. 15). https:/ / doi.org/10.28945/3536

Türk, E., \& Erçetin, G. (2014). Effects of interactive versus simultaneous display of multimedia glosses on L2 reading comprehension and incidental vocabulary learning. Computer Assisted Language Learning, 27(1), 1-25. https:/ / doi.org/10.1080/09588221.2012.692384

Uysal, A. K., \& Gunal, S. (2014). The impact of preprocessing on text classification. Information Processing $\mathcal{E}$ Management, 50(1), 104-112. https:/ / doi.org/10.1016/j.ipm.2013.08.006

Wu, T., Tai, Y. (2016). Effects of Multimedia Information Technology Integrated Multi-Sensory Instruction on Students' Learning Motivation and Outcome. Eurasia Journal of Mathematics, Science and Technology Education, 12(4), 1065-1074. https: / / doi.org/10.12973/ eurasia.2016.1552a

Yi, G. (2017). Design Research on the Network Multimedia Courseware for Art-Design Teaching. Eurasia Journal of Mathematics, Science and Technology Education, 13(12), 7885-7892. https:/ / doi.org/10.12973/ejmste/80722

Yuan, L., Powell, S., \& CETIS, J. (2013). MOOCs and open education: Implications for higher education. Cetis White Paper.

\section{http://www.ejmste.com}

